always generally accepted. Dr. Kinnear's book is as good as any of its type produced in this country ; it has long been and will continue to be popular with students.

$$
\text { D.I.W. }
$$

\section{DERMATOLOGY FOR NURSES}

By G. H. Percival, M.D., Ph.D., F.R.C.P.E., D.P.H., and Elizabeth Toddie, S.R.N. E. \& S. Livingstone, Ltd. I947. Pp. I I6. Price I5s.

Few nurses have the opportunity in their training to see diseases of the skin, fewer still get practical experience in treating them. Yet in no other branch of medicine does so much depend on skilful application of local remedies. This book has, therefore, been designed to stimulate interest in the subject and to fill the gap in the training of those nurses who are not fortunate enough to work for a time in a skin ward or out-patient department. Only the very common conditions are, of course, discussed, including all that may be required by the examiners. The chapter on treatment with its stress on local applications and how to use them, is the best and most valuable feature of the book. The black and white illustrations are mostly very good ; those in colour, especially of psoriasis, are disappointing. It can be fairly said that this volume more than adequately fulfills its purpose and any nurse with interest in her profession would do well to read it. The price of fifteen shillings seems high. Could it not have been made more within the reach of the nurse's pocket if the illustrations had all been in black and white?

\section{D.I.W.}

\section{RESEARCH IN HOLLAND-EXPERIMENTAL EMBRYOLOGY}

By M. W. Woerdeman and Chr. P. Raven. Cleaver-Hume Press, Ltd. 1946. I3s. net.

Under the very great difficulties of occupation and war some Dutch biologists managed to continue work on the fundamental processes of development. Professor Woerdeman, the author of this summary of the work was himself wanted by the Germans and for many months did not sleep for two consecutive nights in the same house; though he says nothing of this in the book!

The summary describes briefly many interesting investigations on the development of amphibia and birds, many of them of the processes of induction such as that of the lens by the eye cup. On account of the limitations of the times no very striking technical innovations were made, but the work increases our knowledge of the fundamental principles of development. The book also includes an account of some very thorough work on the cytology of snails whose general importance is that it reveals details of the extrusion of yolk material from the nucleus and of the association of the Golgi bodies with special redox systems ; any clue to the functions of individual cell organs is welcome.

F.Z.Y.

\section{PENIGILLIN IN SYPHILIS}

By J. EARLE Moore, M.D. Blackwell Scientifin Publications, Oxford. 1947. Pp, 3 19. Price्e 27s. 6d.

Since 1933 when Dr. Moore's book, ironically, he himself points out, entitled 'The Moder 'Treatment of Syphilis,' was first published, it has. been the final arbiter of many an argument between venereologists. The clarity of his writing, the soundness of his judgment and the essential righto ness of his views make it a pleasure to review any? thing he writes. This new volume (published twelve months ago in America) must be regarded as 'tentative, preliminary and supplementary' to the larger volume. It is a summary of a nation-wife co-operative study, initiated under the pressure ff war and urgent public health problems. It seems pity that there is not, to any extent, similar cof operative study of these or like problems in this country. So many problems can only be solved big the study of a large series of cases. Dr. Moore has incorporated results both from the co-operatios study and from the literature, sifting critically the mass of material and presenting the results $\log$ ? cally, clearly and with authority. He takes the view, and rightly, that " although new developments are constantly occurring, it is nevertheless worth white to describe the best methods of tre itment now use and to relate the attainable results.' The trgatment of syphilis is in such a state of flux that ong anchor, even a temporary sea-anchor must bee welcomed.

The effects of penicillin can be more easil appraised in early syphilis, in syphilis complicating pregnancy and in neuro-syphilis. The bulk of the information presented on treatment concerns thes 8 phases of the disease. The difficulties of assessment and the scanty literature available on penicillin if the treatment of syphilis of the cardiovascular system are reflected by the fact that the subject covered in three pages. There are other chapters ot latent syphilis, ocular syphilis, benign late syphilig congenital syphilis and an important chapter on the. dangers of penicillin administered for other purs poses as a source of confusion in the diagnosis of syphilis. The first half of the book is concerned wit fundamental information on the pharmacolog chemistry and mode of action of the various peng cillins. Intelligent use of penicillin in the treatment of syphilis demands an understanding of these firs principles.

Except in so far as there is an increasing tendeney nowadays to use penicillin on an ambulatory basis either once daily in oil and beeswax, or by twiç daily injections in saline or water, there has bees little change since this work first went to print. $\bar{f}$ can be thoroughly recommended as a theoretica and practical guide to the treatment of syphilis with penicillin, written with the proscience, but not with the wild surmise, of Dr. Moore's ancient namesake's almanack. 